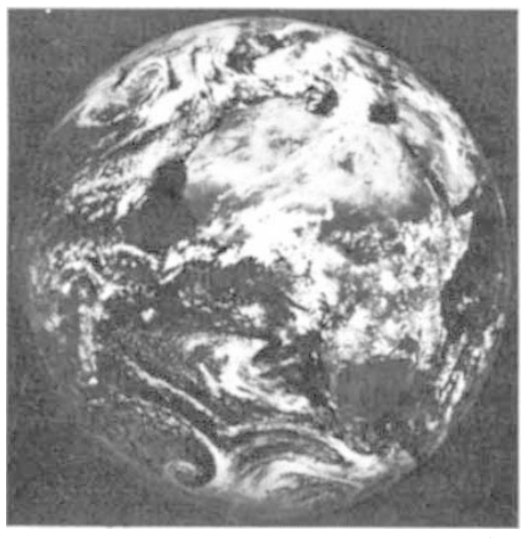

METEOSAT Cloud patterns seen by satellite

Many scientists, however, fear the problems that could arise from interagency disagreements over who should take responsibility for what. This has, for example, happened in the past in disputes between the Departments of Agriculture and the National Aeronautic and Space Administration over crop forecast programmes, or the Department of Energy's involvement in assessing the impact of $\mathrm{CO}_{2}$ emission.

Such concern is reflected in a report on the two versions of the proposed legislation which has been prepared by the President's National Advisory Committee on Oceans and Atmosphere (NACOA), an independent body responsible to both the President and Congress.

It is concerned primarily with showing how the similar versions of a climate bill could be relatively easily reconciled and also suggests that the President's science adviser, the director of the Office of Science and Technology Policy, should have prime responsibility for co-ordinating the programme and its budget.

"This will ensure considerations of the programme as a coherent executive branch activity, rather than as an effort shaped largely by the policies of any one agency," the NACOA report states.

OSTP is said to be less than happy with this proposal, partly because of a lack of sufficient resources and other pressures of work. Unlike most of the other suggestions made by NACOA, such as they are, that university research on climate issues of national importance should be $100 \%$ federally funded, this one will not be taken up fully into the legislation, although OSTP may be given formal responsibility for the programme.

Much will therefore depend on the individual who is selected to head the climate programme, and whether he or she has the skills and status to overcome interagency differences. But like the weather itself, political forecasting is an unpredictable activity.

David Dickson

\title{
New head of French research appointed
}

IN APPoInTing Pierre Aigrain to head French scientific research, the government of M. Raymond Barre has chosen a scientist rather than a technocrat or politician. He is already well known in scientific research in France.

Aigrain started off specialising in electronics and initiated the study of semiconductors in France. He later travelled widely, finding out about the organisation of research in other countries. Returning to France, he showed his versatility by alternating between applied science, fundamental research and higher education, working for the National Centre for Scientific Research (CNRS), the Collège de France, the École Normale Superieure, the Faculty of Science and the Atomic Energy Authority. From 1968 to 1973 he was general adviser on scientific and technical research, a position close to the Prime Minister.

So far, Aigrain's research policy is unknown, if only because he has not yet named his advisers. But it is worth noting that from 1973 he was scientific organiser in the Giscard group 'Perspective and reality', and that he succeeded Barre on 1 March, 1977 as chief of higher scientific study. It is likely that, as well as following the priorities defined in the Grand Plan, the new Secretary of State for Research will reflect on the advice given last year by the consultative committee on technical and scientific research (CCRST). It pinpointed the following problems:

- The necessity for a strong scientific and technical research policy.

- The need for more freedom of choice in applied science, combined with a long term industrial strategy (an area in which Aigrain should have many ideas; he was technical directorgeneral with the Thomson CSF Company until his government appointment).

- The decline in productivity of research workers.

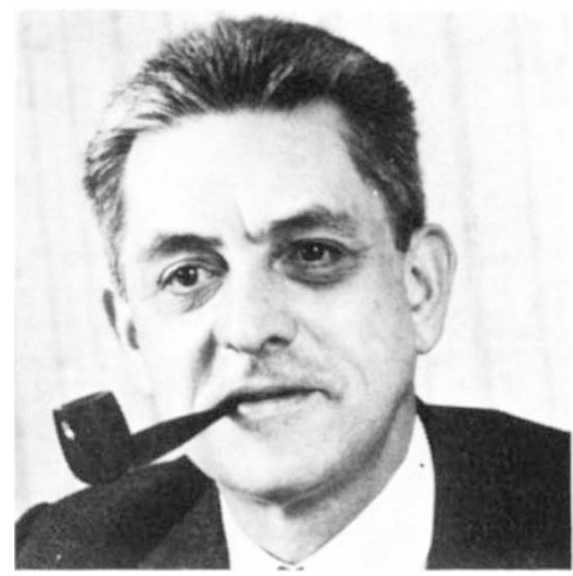

Pierre Aigrain: scientist not technocrat

Finally, the CCRST report says it is important to put right the imbalances in French scientific research, such as the erosion of fundamental research and industrial research, limited international cooperation, and the lack of support in areas like bio-medicine, bioagronomy, oceanology and new forms of energy.

\section{Soviets rap birch-sap tappers}

BIRCH-SAP tapping is a traditional spring-time delight among the east Slavs, indeed, the Byelorussian and Ukrainian words for 'March' seem derived from this practice. Although the careful sap-drinker, wishing to conserve his supply of the juice (which may be compared with maple syrup), would always take care to close the 'wound' after tapping, heedless tapping can result in the loss of the tree. Havoc is being wreaked in Soviet birchforests.

Even in the last century, the Byelorussian didactic poet Jan Cacot found it necessary to include a warning against careless tapping in a collection of verses otherwise devoted to the virtues of work and the evils of hard liquor. Although birch-tapping has long since become a Soviet state monopoly, with private operations punishable by law, unskilled tappers are still about and are causing considerable loss of trees. In a recent radio interview,
Mikhail G. Chervonnyy, deputy head of the Chief Directorate for Forest Protection of the Russian SFSR explained that "it is no secret" that many saploving "tourists" attack the trees indiscriminately with axes, so that the tree of ten perishes through loss of sap. The state-appointed experts, of course, use special techniques which do not harm the tree.

Chervonnyy explained the proper procedure: the incision must be made by a $2-\mathrm{cm}$ drill, to a depth of up to $3 \mathrm{~cm}$, and not higher than $30 \mathrm{~cm}$ from the ground. After sap-running is completed, the incision must be closed by a special putty. Unfortunately the talk rather took the form of an instruction course for the sap-poacher. One can only wonder if, finding it impossible to stop illegal tapping, the Directorate had decided on this somewhat pragmatic method of preventing permanent damage to the trees.

Vera Rich 